\title{
Pengaruh jenis umpan terhadap hasil tangkapan pancing dasar sekitar perairan Desa Bajo Kabupaten Minahasa Selatan Provinsi Sulawesi Utara
}

The influence of bait types on catches of bottom hand line in waters of Bajo Village, South Minahasa Regency, North Sulawesi Province

\author{
LABAN AMBER*, FANNY SILOOY dan MARIANA E. KAYADOE \\ Program Studi Pemanfaatan Sumberdaya Perikanan, Fakultas Perikanan dan Ilmu Kelautan, \\ Universitas Sam Ratulangi, Manado 95115
}

\begin{abstract}
The use of bottom hand line with the various types of live baits provide satisfactory catches but fishermen are not sure which natural bait (fish) being the most suitable and giving more catches. Of commonly used baits, three type of baits had been chosen, i.e. scad mackerel, round scad and squid. This study used a randomized block design and LSD test. The result showed that the best bait for bottom hand line is scad mackerel with catches of 59 individuals, followed by round scad with 41 individuals and squid with 37 individuals. The composition of the catch is gaca (Lutjanus Gibus) with the highest number of 40 fish, gutila (Lethanus oratus) 30 fish, snappers (Lutjanus sp) 28 fish, goropa (Cepolopholis minata) 23 fish and fish tato (Eedonus niger) only 16 fish.
\end{abstract}

Keywords: hook and line, bait, Bajo village.

\begin{abstract}
ABSTRAK
Penggunaan pancing dasar dengan berbagai jenis umpan hidup memberikan hasil tangkapan yang cukup memuaskan namun nelayan belum mengetahui penggunaan umpan alami (ikan) apa yang paling cocok dan memberikan hasil terbanyak. Dari beberapa jenis umpan ikan yang biasa digunakan, maka dipilih tiga jenis ikan yang dijadikan umpan yaitu ikan malalugis, tude dan cumi. Penelitian ini menggunakan rancangan acak kelompok dan uji BNT. Hasil analisis menunjukkan bahwa umpan yang terbaik untuk pancing dasar adalah ikan malalugis dengan jumlah hasil tangkapan terbanyak yaitu 59 ekor, diikuti oleh ikan tude dengan hasil tangkapan 41 ekor dan cumi dengan hasil tangkapan 37 ekor. Komposisi hasil tangkapan adalah ikan gaca (Lutjanus gibus) dengan jumlah tertinggi sebanyak 40 ekor, gutila (Lethanusoratus) 30 ekor, gorara (Lutjanus sp) 28 ekor, goropa (Cepolopholis minata) 23 ekor dan ikan tato (Edonus niger) hanya 16 ekor.
\end{abstract}

Kata-kata kunci: pancing dasar, umpan, Desa Bajo

\section{PENDAHULUAN}

Secara ideal, pembangunan perikanan di Minahasa Selatan seharusnya diarahkan secara serasi, merata dan terpadu untuk mencapai usaha perikanan yang maju, efisien dan tangguh. Konsep pembangunan ini ditunjang olah ketersediaan sumberdaya laut yang sebagian besar belum dimanfaatkan.

Pengelolaan dan pemanfaatan sumber daya perikanan laut bertujuan untuk meningkatkan kesejahteraan dan taraf hidup masyarakat.
Masyarakat Desa Bajo adalah masyarakat nelayan dari beberapa jenis alat tangkap ikan, dan salah satu jenis alat yang sering digunakan oleh nelayan Bajo adalah pancing dasar. Penggunaan pancing dasar dengan beberbagai jenis umpan hidup memberikan hasil tangkapan yang cukup memuaskan namun nelayan belum mengetahui penggunaan umpan alami (ikan) apa yang paling cocok dan memberikan hasil terbanyak. Dari beberapa jenis umpan ikan yang biasa digunakan,

\footnotetext{
*Penulis untukpenyuratan; email: labanamber@yahoo.com
} 